\title{
Influence of Mulching Material on Albinism Disorder in Strawberry under Cold Arid Conditions
}

\author{
R.A. Wani*, Jahangeer A. Baba, S.A. Hakeem, Umar, I. Ashaq H. Pandit, M.A. Mir, Mohd \\ Zubair, Sabiya Bashir, Seerat-un-Nissa, Niyaz A. Dar and G.A. Parray \\ HMAARI, Dryland Agriculture Research Station, Budgam SKUAST-K, Leh, \\ Ladakh, J \& K, 194 101, India \\ *Corresponding author
}

\section{A B S T R A C T}

Albinism is a serious disorder of strawberry in which fruits appear bloated, develop poor color flavor and become susceptible to fruit rot during storage. Many factors have been reported to be associated with albinism, but vigorous vegetative

Keywords

Mulching,

Strawberry,

Albinism

Article Info

Accepted:

29 June 2017

Available Online:

10 July 2017 growth of the plant is considered as the primary factor. Strawberry is one of the most delicate fruit, which is grown commercially in temperate climatic conditions of the world. For its successful cultivation, mulching is considered as most useful cultural practice. Mulching helps in better conservation and utilization of hydrothermal regimes, which helps in better growth and yield. Three mulch materials (Black polyethylene, White polyethylene, and Paddy Straw) were evaluated to reduce albinism in five cultivars of strawberry. Fruits suffering from albinism appear bloated, develop poor colour, are liable to serve damage during harvesting and become highly susceptible to fruit rot during storage. The incidence of albinism was highest $(38.60 \%)$ with black polyethylene and lowest with paddy straw (22.65\%). Among cultivars, Erna had the highest incidence of albinism $(50.60 \%)$ followed by chandler $(41.60 \%)$, where as Sweet Charlie had the least.

\section{Introduction}

Strawberry is one of the most delicious and refreshing fruit in world, which is cherished in gardens for its beautiful, attractive fruit that has a tantalizing aroma. Though it is a major fruit of temperate climates, it also grows profitably well in subtropical plains of India (Sharma et al., 1999). It suffers from many disorders, but albinism is considered as most serious disorder of its fruits, occurring primarily at the time of ripening. It is particularly serious in greenhouse grown strawberries, which has reached an alarming situation in USA, Belgium and the Netherlands (Lieten et al., 1993), though (Sharma et al., 2002) has also observed its incidence in field grown strawberries under sub-tropical climates. Fruits suffering from albinism appear bloated and develop white or pink areas on its surface and its pulp remains pale. It has a poor flavour and tends to be more acidic than a normal fruit. Similarly, the affected fruit does not ripe uniformly, is liable 
to be severely damaged during harvesting and is highly susceptible to fruit rot during storage (Lieten et al., 1993, Sharma et al., 2002). The marketing of such a fruit is very difficult, and, if marketed, it fetches a very poor price, giving to farmers fewer returns for their investment (Sharma et al., 1999, Sharma et al., 2002).

Strawberry is one of the most delicate fruit, which is grown commercially in temperate climatic conditions of the world. However, with the development of day-neutral varieties, it grows profitably well in tropical and subtropical climatic condition of India (Sharma, 2002). For its successful cultivation, mulching is considered as most useful cultural practice. Mulching helps in better conservation and utilization of hydrothermal regimes, which helps in better growth and yield. For mulching, different materials are used but black polyethylene is used commercially all over the world (Tarara, 2000). Under tropical and subtropical climates, strawberry suffers from many disorders, but albinism is considered as most of the serious disorder of strawberry fruit, occurring primarily at the time of fruit maturity or ripening.

Fruits suffering from albinism appear bloated, develop poor colour, are liable to serve damage during harvesting, become highly susceptible to fruit rot during storage (Lieten and Marcelle, 1993) and fetch very poor price in the market. Many reasons could be attributed to albinism, but excessive growth of the runners occurring due to heavy nitrogen fertilization is mainly associated with it and mulching materials may influence it invariably (Badiyala and Aggarwal, 1981; Himelrick et al., 1983; Lieten and Marcelle, 1993; Sharma and Sharma, 2004). Though it is a serious disorder in greenhouse grown strawberry but in the recent years, its incidence has been observed in field grown strawberry as well (Sharma and Sharma, 2003). In cold arid regions of India strawberry is mostly grown under poly house conditions and hence, the systematic studies were conducted to observe the effect of different mulch materials on albinism incidence in strawberry.

\section{Materials and Methods}

The studies were conducted in the research field of High Mountain Arid Agriculture Research Institute (formerly Regional Agriculture Research Station) SKUAST-K Leh in the year 2011-12. Two hundred runners each of the five varieties viz. Sweet Charlie, Douglas, Chandler, Fern and Etna, were planted on the raised beds at a distance of $30 \times 45 \mathrm{~cm}$ during the last week of October each year. Black polyethylene (BP), White polyethylene (WP) and Paddy Straw (PS) were applied as mulch materials to the runners after 15 days of planting, while no mulch was applied to the control plants. Each treatment consisted of three beds, replicated three times. Observations on albinism incidence (\%) was recorded by counting healthy and albino fruits in five randomly selected plants/bed and expressed as percentage $(\%)$. The data of two years was pooled and subjected to analysis following RBD factorial design (Panse and Sukhatme, 1984).

\section{Results and Discussion}

Nearly 33 per cent strawberry fruits were affected by albinism under field grown conditions. Such report has been presented by Sharma and Sharma (2003), which was the first report in the world on the occurrence of albinism in field grown strawberries. In the present studies, albinism incidence was the highest when plants were mulched with black polyethylene $(38.68 \%)$ and least $(22.65 \%)$ in the plants mulched with Paddy Straw (Table 
1). In case of control, plants produced as high as 36.81 per cent albino fruits. The incidence of albinism was influenced by mulching, being significantly high with black polyethylene and very less in case of Paddy straw, which may probably due to better growth of plants under black polyethylene mulch compared to other mulch materials and control (Lieten and Marcelle, 1993). In addition, black polyethylene mulch is also known to promote nitrogen mineralization, which might have also favoured the incidence of albinism (Renquest et al., 1977; Tarara, 2000). Albinism incidence was observed to be lesser in plants mulched with paddy straw (22.65\%) signifying its importance over other mulch materials under subtropical climate. Among different cultivars, the incidence of albinism was highest in Etna $(50.60 \%)$ and least in Sweet Charlie (22.50\%).

Table.1 Effect of different mulch materials on albinism incidence in strawberry

\begin{tabular}{|l|l|l|l|l|l|}
\hline \multirow{2}{*}{ Cultivars } & \multicolumn{3}{|c|}{ Albinism incidence (\%) } & \multirow{2}{*}{ Mean } \\
\cline { 2 - 5 } & \multicolumn{3}{|c|}{ Mulching materials } \\
\cline { 2 - 5 } & $\begin{array}{l}\text { Black } \\
\text { polyethylene }\end{array}$ & $\begin{array}{l}\text { White } \\
\text { Polyethylene }\end{array}$ & $\begin{array}{l}\text { Paddy } \\
\text { straw }\end{array}$ & control & \\
\hline Sweet Charlie & 28.40 & 23.30 & 11.75 & 26.50 & 22.50 \\
\hline Chandler & 46.56 & 41.60 & 32.75 & 45.60 & 41.60 \\
\hline Douglas & 30.34 & 22.98 & 12.65 & 29.75 & 23.93 \\
\hline Fern & 30.92 & 25.22 & 11.35 & 31.60 & 23.70 \\
\hline Etna & 56.76 & 48.39 & 43.75 & 50.60 & 50.60 \\
\hline Mean & 38.62 & 32.90 & 22.65 & 36.81 & 32.71 \\
\hline
\end{tabular}

$\mathrm{CD}$ at $5 \%$ Mulch $=1.98, \quad$ Cultivar $=1.95, \quad$ Mulch $\times$ Cultivar $=2.66$

Fig.1 Effect of different mulch materials on albinism incidence in strawberry

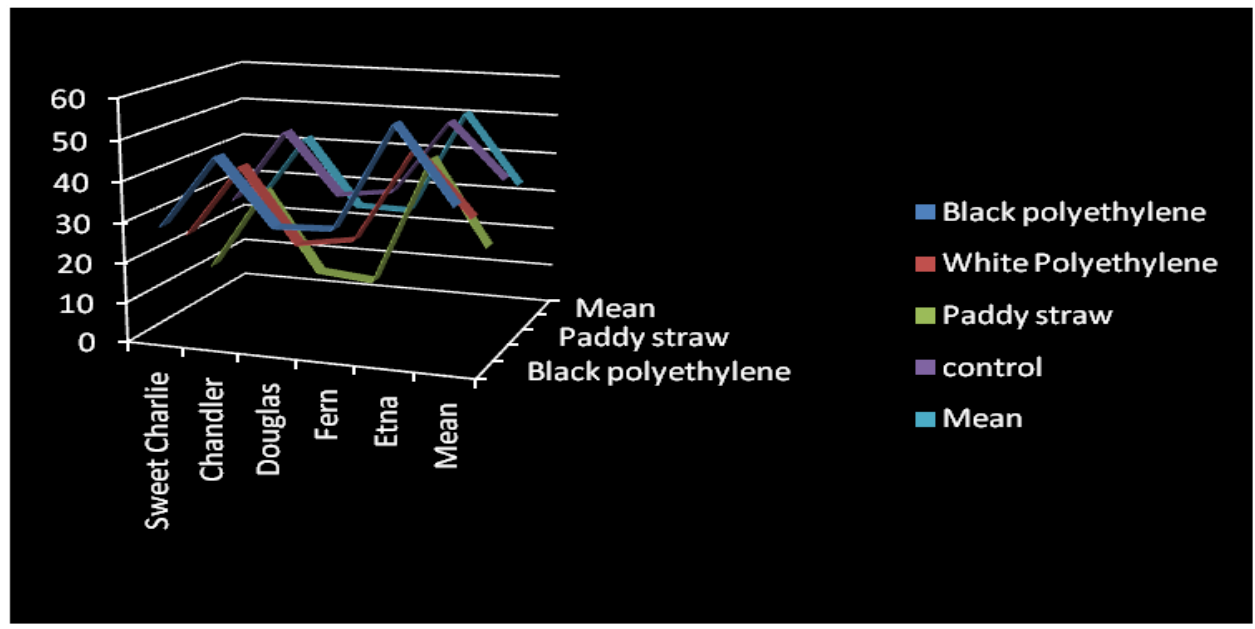


The wider availability in respect to albinism among different cultivars may be genetic variability related to vigourness of plants. In general, cultivars having vigorous growth (e.g., Etna) produce albino fruits in higher proportion and vice versa (Sharma and Singh, 1999; Sharma and Sharma, 2004) (Fig. 1).

The interaction, mulch $\mathrm{x}$ cultivar for the albinism incidence was significant with the highest production of albino fruits in Etna $(56.76 \%)$ under black polyethylene mulch and lowest in Sweet Charlie (11.75\%) under paddy straw mulch. It may be due to synergistic influence of genetic variability and black polyethylene on albinism incidence.

\section{References}

Badiyala, S. O. and Aggrawal, G. C. 1981. Note on the effect of mulching on strawberry production. Indian J. Agri. Res., 51: 832-834.

Himelrick, D. G., Dozier, W. A. and Akridge, J. R. 1983. Effect of mulch types in annual hill strawberry plantations. Acta Horticulture, 348: 207-212.

Lieten, F. and Marcelle, R. D. 1993. Relationship between fruit mineral content and the albinism disorder in strawberry. Ann. Appl. Biol., 123: $433-$ 439.

Panse, V. G. and Sukhatme, P. V. 1984. Statistical methods for Agricultural workers, $4^{\text {th }}$ Edition ICAR, New Delhi India.

Renquest, A. R., Breen, D. J. and Martus, P. G. 1977. Effect of polyethylene mulch and summer irrigation regimes on subsequent flowering and fruiting of Olympus strawberry, J. Amer, Soc. Hort. Sci., 107: 373 - 376.

Sharma, 2002. Growing strawberry. International Book Distributing Co., Lucknow, India.

Sharma, R. R. and Sharma, R. P. 2003. Mulch type influences plant growth, yield and albinism incidence in strawberry (Fragaria x anansssa). Fruits, 58 (4): 221-227.

Sharma, V. P. and Sharma, R. R. 2004. The strawberry. ICAR, New Delhi, India, pp 166.

Sharma, R. R. and Singh, S. K. 1999. Strawberry cultivation: A highly remunerative farming enterprise. Agro India, 3: 20 - 22 .

Tarara, J. M, 2000. Microclimate modification with plastic mulch. Hort. Science 35: 169-180.

\section{How to cite this article:}

Wani, R.A., Jahangeer A. Baba, S.A. Hakeem, Umar, I. Ashaq, H. Pandit, M A. Mir, Mohd Zubair, Sabiya Bashir, Seerat-un-Nissa, Niyaz A. Dar and Parray, G.A. 2017. Influence of Mulching Material on Albinism Disorder In Strawberry under Cold Arid Conditions. Int.J.Curr.Microbiol.App.Sci. 6(7): 4287-4290. doi: https://doi.org/10.20546/ijcmas.2017.607.444 